\title{
A new Brazilian species of Psychoda Latreille, 1796 \\ (Diptera, Psychodidae) collected in a bromeliad
}

\author{
Freddy Bravo $^{1,2}$, Priscila Silva Lopes ${ }^{1} \&$ Scheilla Bastos ${ }^{1}$ \\ ${ }^{1}$ Departamento de Ciências Biológicas, Universidade Estadual de Feira de Santana - UEFS, \\ Av. Transnordestina, s/n, CEP 44036-900, Feira de Santana, BA, Brazil \\ ${ }^{2}$ Correspondence author: Freddy Bravo,e-mail: fbravo@uefs.br
}

BRAVO, F., LOPES, P.S. \& BASTOS, S. A new Brazilian species of Psychoda Latreille, 1796 (Diptera, Psychodidae) collected in a bromeliad. Biota Neotrop. 10(2): http://www.biotaneotropica.org.br/v10n2/en/ abstract?article+bn04110022010.

Abstract: A new species of Psychoda Latreille is described from Brazil. It is the first species of the genus to be collected in a bromeliad. The number of known Psychoda species from Brazil has increased to seven with this description of Psychoda romeroi sp. nov.

Keywords: Psychodinae, Psychoda, Neotropical Region, Brazil, new species, bromeliad.

BRAVO, F., LOPES, P.S. \& BASTOS, S. Espécie nova de Psychoda Latreille, 1796 (Diptera, Psychodidae) do Brasil coletada em bromélia. Biota Neotrop. 10(2): http://www.biotaneotropica.org.br/v10n2/pt/ abstract?article+bn04110022010.

Resumo: Uma nova espécie brasileira de Psychoda Latreille, 1796 (Diptera, Psychodidae) coletada em bromélia. É descrita, pela primeira vez, uma nova espécie de Psychoda Latreille coletada em bromélia. O número atual de espécies brasileiras de Psychoda aumentou para sete com a descrição de Psychoda romeroi sp. nov.

Palavras-chave: Psychodinae, Psychoda, Região Neotropical, Brasil, nova espécie, bromélia. 


\section{Introduction}

Some species of bromeliads, an essentially American plant group, contain rich insect faunas that include species of aquatic Diptera (see Kitching 2000 for a revision of this subject). Psychodid larvae have been observed in abundance in bromeliad phytoltemata (Frank \& Lonibos 2009). Few species of Psychodidae have been collected in bromeliads. Frank et al. (2004) studied the Diptera fauna associated with bromeliads in Florida and reported 190 larvae and pupae of Alepia Enderlein, 1937, but did not provide specific identifications. Knab (1914) described three species: Philosepedon fumata (Knab, 1914) from Mexico; Neurosystasis amplipenna (Knab, 1914) from Cuba; and Alepia tricolor (Knab, 1914) from Panama. Three other species of Alepia have been described in association with bromeliads: Alepia symmetrica Wagner \& Hribar, 2005 from Florida Keys; Alepia zavortinki Wagner, Richardson \& Richardson, 2008 from Puerto Rico; and Alepia vaga Wagner \& Svensson, 2006 described from Sweden, although the adults probably emerged from a bromeliad imported from Brazil (Wagner \& Hribar 2005, Wagner \& Svensson 2006, Wagner et al. 2008).

The genus Psychoda Latreille, 1796 currently comprises 59 species in the Neotropical Region (Bravo et al. 2006, Cordeiro $\&$ Bravo 2008), six of them from Brazil. In the present paper, a new species of Psychoda is described from the State of São Paulo, Brazil, based on a single imago and his pupal exuviae sent us by Gustavo Romero.

\section{Material and Methods}

Morphological studies of the adult and his pupal exuviae were based on slide-mounted. The adult and his pupal exuviae were mounted in independent slides and they received the same museum number. Slides were prepared using potassium hydroxide to clear specimens and Canada balsam as a mounting medium. Morphological terminology follows that of McAlpine (1981). Terminology specific to Psychodidae follows Duckhouse (1990), Bravo (2006) and Curler $\&$ Moulton (2008). The adult and pupal exuviae were deposited in the Coleção Entomológica Prof. Johann Becker do Museu de Zoologia da Universidade Estadual de Feira de Santana, Brazil (MZUEFS).

\section{Results}

Psychoda romeroi Bravo, Lopes \& Bastos, sp. nov. (Figures 1-13)

Material examined. Type material. BRAZIL, São Paulo, Ilha do Cardoso, 29.I.2008, Srisvastava, D. \& Romero, G. leg., holotype female with pupal exuviae mounted in Canada balsam (\#44595, MZUEFS).

Diagnosis. Frons and vertex pilose with small glabrous, V-shaped area at the apex of the head; labellum with six teeth, four apical and two subapical; medial fork basad of radial fork; $\mathrm{M}_{1}, \mathrm{CuA}_{1}$ and $\mathrm{CuA}_{2}$ not reaching the margin of the wing; genital digit absent.
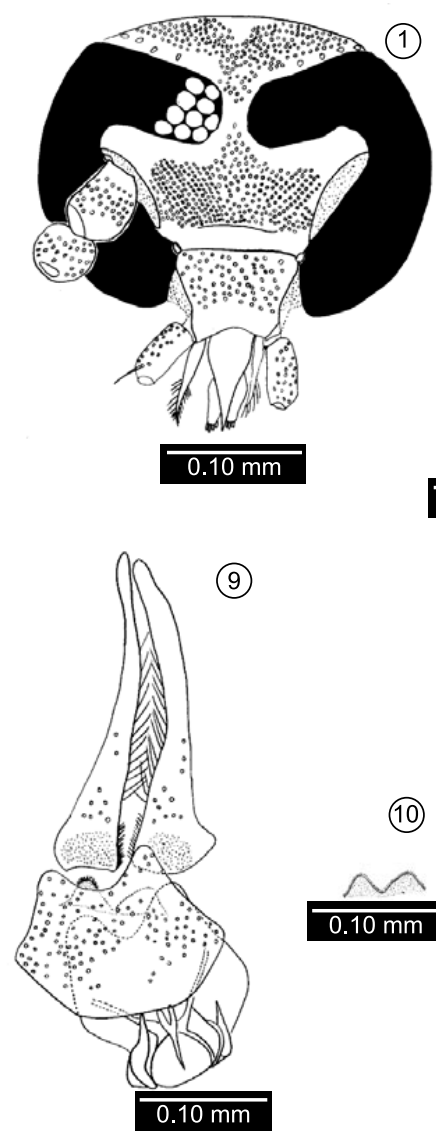

(10)

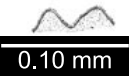

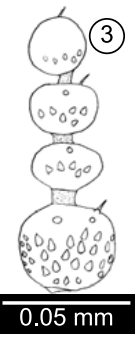
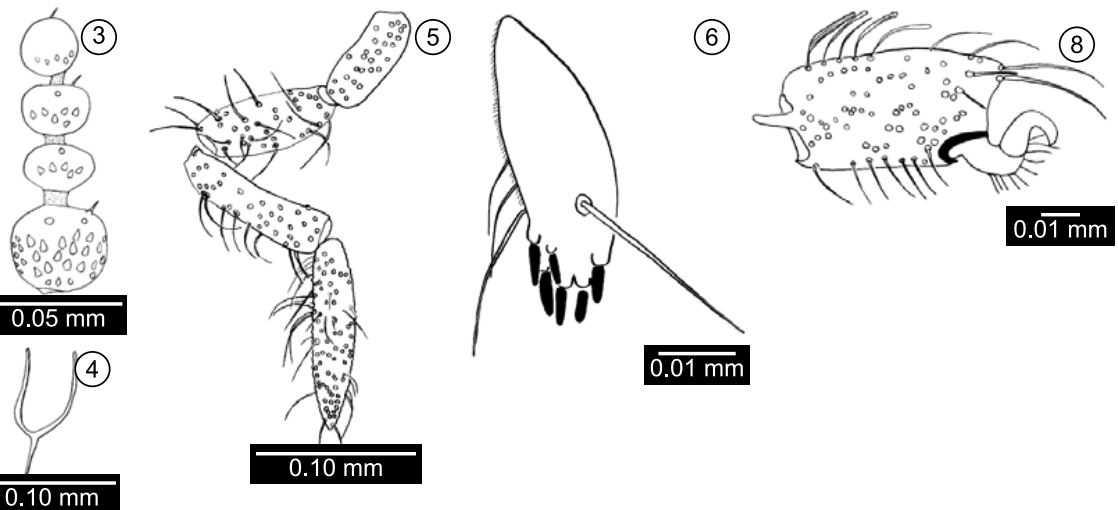
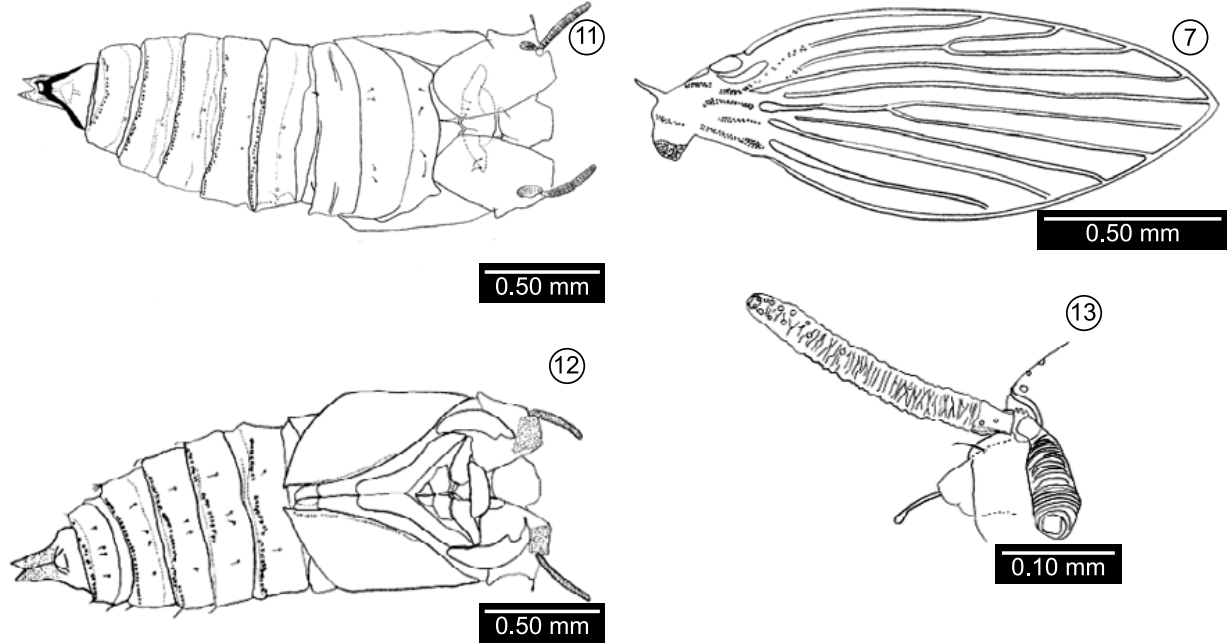

Figures 1-13. Psychoda romeroi Bravo, Lopes \& Bastos, sp. nov., female. 1. Head. 2. Antenna: scape, pedicel and basal flagellomeres. 3. Antenna: flagellomeres 11-14, flagellomeres 11, 13 and 14 with spine. 4. Ascoid. 5. Palpus. 6. Labellum. 7. Wing. 8. Fore distitarsus. 9. Female terminalia, ventral view. 10. Bilobate structure on the internal face of plate. 11. Pupa, dorsal. 12. Pupa, ventral. 13. Pupa, respiratory horn. 
Description. Female. Head width, $0.29 \mathrm{~mm}$; head height from base of clypeus to vertex, $0.30 \mathrm{~mm}$; palpus length, $0.23 \mathrm{~mm}$; wing length, 1,31 mm; wing width, $8.1 \mathrm{~mm}$; cercus length, $0.02 \mathrm{~mm}$. Frons and vertex pilose (Figure 1); vertex with small glabrous, V-shaped area at the apex of the head (Figure 1); four postocular alveoli (Figure 1); hair patch of the frons extends to the second facet row (Figure 1); eye bridge with four facet rows (Figure 1); eyes separated by 1.7 facet diameters (Figure 1). Interocular suture absent (Figure 1). Antenna with 14 flagellomeres, $1^{\text {st }}-10^{\text {th }}$ nodiform (Figure 2), $12^{\text {th }}-14^{\text {th }}$ reduced, not fused (Figure 3 ), $11^{\text {th }}-13^{\text {th }}$ with short neck; $14^{\text {th }}$ subspherical (Figure 3); flagellomeres 11, 13 and 14 with spine (Figure 3); ascoids Y-shaped (Figure 4); scape cylindrical, 1.5 times as long as the pedicel (Figure 2); pedicel subspherical (Figure 2). Palpus formula $=1.0: 1.1: 1.3: 1.7$ (Figure 5). Labellum with six teeth of the same length, four apical and two subapical, with four long bristles, three of them lateral (Figure 6). Wing (Figure 7): Sc short, wide, not reaching the base of Rs; base of $R_{1}$ and $R_{2}$ incomplete; medial fork basad of radial fork; $\mathrm{M}_{1}, \mathrm{CuA}_{1}$ and $\mathrm{CuA}_{2}$ not reaching the wing margin. Fore distitarsus with a small, dorsal and apical projection (Figure 8). Female terminalia (Figures 9, 10): cercus long, 2.5 times as long as the length of subgenital plate; subgenital plate with distal margin arched; bilobate structure on the internal face of plate (Figure 10); genital digit absent; spermatheca as shown in Figure 9.

Pupa (Figures 11-13). Color light brown; Body ovoid from dorsal view; tips of legs not extending beyond the apices of the wing covers; respiratory horn eight times as long as its central width, with irregular double rows of pits extending one-quarter of the way down from the tip of the horn; few pits in the basal three-quarters of the horn. Dorsal and ventral surfaces with few microtrichia. Distal margin of abdominal tergites and sternites with minute spiniform tubercles.

Male. Unknown.

Etymology. The species epithet is dedicated to Gustavo Romero who collected and sent us the specimen.

Biological notes. According to Gustavo Romero (pers. comm.), the specimen emerged from water spilled and stored, for ecological study, of Quesnelia arvensis (Vell.) Mez, an endemic bromeliad of the Atlantic Coastal Forest distributed from Rio de Janeiro State to Paraná State (Vieira 2006).

\section{Discussion}

The features that distinguish the new species $P$. romeroi from other Neotropical species are the presence of six long teeth and two bristles on the labella. The cosmopolitan species Psychoda cinerea Banks, 1894, has six teeth on the labella, with five of them being long and one short (Duckhouse 1966: Fig. 204). Also P. cinerea has five long bristles on the labella, not four as in the new species described here. The Neartic species Psychoda tothastica Quate, 1.955 lost the genital digit as the new species here describe, but $P$. tothastica has five teeth, and three long bristles on the labella, and the eyes are separated by distance equal to one facet diameter, whereas $P$. romeroi $\mathrm{sp}$. nov. has six teeth and four long bristles on the labella and the eyes are separated by distance equal to 1.7 facet diameter.

P. romeroi sp. nov. is the first species of the genus Psychoda to be found in a bromeliad, however, at least two other species of
Psychoda, P. savaiiensis Edwards, 1928 and P. parsivena Quate, 1959, are associated with other species of phytotelmata (Kitching 2000). With the description of this species, the number of known Psychoda species from Brazil has increased to seven.

\section{Acknowledgements}

FB received a research grant from CNPq (306426/2006-4). PSL received a $\mathrm{PIBIC/CNPq}$ grant. SB received a PROBIC/UEFS grant.

\section{References}

BRAVO, F. 2006. The taxonomy of Neotropical Brunettiina (Diptera, Psychodidae, Psychodinae, Mormiini), with descriptions of ten new species from Brazil and comments on the generic classification of the subtribe. Zootaxa 1134:1-28.

BRAVO, F., CORDEIRO, D. \& CHAGAS, C. 2006. Two new species and new records of Psychoda Latreille (Diptera: Psychodidae: Psychodinae) from Brazil, with comments on supraspecific classification of the genus. Zootaxa 1298:1-15.

CORDEIRO, D. \& BRAVO, F. 2008. A new species of viviparous moth fly (Diptera, Psychodidae, Psychodinae) from the Brazilian Amazon. Biota Neotrop. 8(2):115-119.

CURLER, G.R. \& MOULTON, J.K. 2008. A review of the Nearctic species of the genus Eurygarka Quate (Diptera: Psychodidae). Zootaxa 1740:28-36.

DUCKHOUSE, D.A. 1966. Psychodidae (Diptera, Nematocera) of Southern Australia: subfamily Psychodinae. Trans. R. ent.Soc. Lond. 118(6):153-220.

DUCKHOUSE, D.A. 1990. The Australasian genera of Pericomoid Psychodidae (Diptera) and the status of related Enderlein genera in the Neotropics. Invertebr. Taxon. 3(6):721-746.

FRANK, J.H. \& LOUNIBOS, L.P. 2009. Insects and allies associated with bromeliads: a review. Terrestrial Arthropod Reviews 1(2):125-153.

FRANK, J.H., SREENIVASAN, S., BENSHOFF, P.J., DEYRUP, M.A., EDWARDS, G.B., HALBERT, S.E., HAMON, A.B., LOWMAN, M.D., MOCKFORD, E.L., SCHEFFRAHN, R.H., STECK, G.J., THOMAS, M.C., WALKER, T.J. \& WELBOURN, W.C. 2004. Invertebrate animals extracted from native Tillandsia (Bromeliales: Bromeliaceae) in Sarasota County, Florida. Florida Entomol. 87(2):176-185.

KITCHING, R.L. 2000. Food webs and container habitats: the natural history and ecology of Phytotelmata. Cambridge University Press, Cambridge.

KNAB, F. 1914. New moth-flies (Psychodidae) bred from Bromeliaceae and other plants. Proc. U. S. Natl. Mus. 46:103-106.

VIEIRA, C.M. 2006. Quesnelia Gaudich (Bromelioideae: Bromeliaceae) do estado do rio de Janeiro, Brasil. Pesqui. Bot. 57:7-102.

WAGNER, R. \& HRIBAR, L.J. 2004. Moth flies (Diptera: Psychodidae) from the Florida Keys with the description of a new Alepia species. Stud. Dipterol. 11(2):505-511.

WAGNER, R. \& SVENSSON, B.W. 2006. The exceptional discovery of a new Neotropical moth fly in Sweden (Diptera: Psychodidae). Stud. Dipterol. 13(1)99-102.

WAGNER, R., RICHARDSON, B.A. \& RICHARDSON, M.J. 2008. A new psychodid species from Puerto Rico tank bromeliads. Stud. Neotrop. Fauna Environ. 43(3):209-216. 